\title{
Article \\ Effect of Co/Ni Substituting Fe on Magnetocaloric Properties of Fe-Based Bulk Metallic Glasses
}

\author{
Jia Guo ${ }^{1,2}$, Lei Xie ${ }^{1,2}$, Cong Liu ${ }^{3}$, Qiang $\mathrm{Li}^{1,2, *}$, Juntao Huo ${ }^{4, *}$, Chuntao Chang ${ }^{5}$, Hongxiang Li ${ }^{6}$ and Xu Ma ${ }^{1,2}$ \\ 1 Xinjiang Key Laboratory of Solid State Physics and Devices, Xinjiang University, Urumqi 830046, China; \\ 1437439380@stu.xju.edu.cn (J.G.); guo15276862660@163.com (L.X.); 15299660877@163.com (X.M.) \\ 2 School of Physics Science and Technology, Xinjiang University, Urumqi 830046, China \\ 3 School of Materials Science and Engineering, Tianjin University, Tianjin 300072, China; \\ liucong010243@163.com \\ 4 Key Laboratory of Magnetic Materials and Devices, Ningbo Institute of Materials Technology \& Engineering, \\ Chinese Academy of Sciences, Ningbo 315201, China \\ 5 School of Mechanical Engineering, Dongguan University of Technology, Dongguan 523808, China; \\ changct@dgut.edu.cn \\ 6 State Key Laboratory for Advanced Metals and Materials, University of Science and Technology Beijing, \\ Beijing 100083, China; hxli@skl.ustb.edu.cn \\ * Correspondence: qli@xju.edu.cn (Q.L.); huojuntao@nimte.ac.cn (J.H.)
}

Citation: Guo, J.; Xie, L.; Liu, C.; Li, Q.; Huo, J.; Chang, C.; Li, H.; Ma, X. Effect of Co/Ni Substituting Fe on Magnetocaloric Properties of Fe-Based Bulk Metallic Glasses Metals 2021, 11, 950. https://doi.org/ $10.3390 /$ met11060950

Academic Editor: Qiang Luo

Received: 15 May 2021

Accepted: 7 June 2021

Published: 11 June 2021

Publisher's Note: MDPI stays neutral with regard to jurisdictional claims in published maps and institutional affiliations.

Copyright: (c) 2021 by the authors. Licensee MDPI, Basel, Switzerland. This article is an open access article distributed under the terms and conditions of the Creative Commons Attribution (CC BY) license (https:/ / creativecommons.org/licenses/by/ $4.0 /)$.

\begin{abstract}
In this work, $\mathrm{Fe}_{80-\mathrm{x}} \mathrm{M}_{\mathrm{x}} \mathrm{P}_{13} \mathrm{C}_{7}(\mathrm{M}=\mathrm{Co}, \mathrm{Ni} ; \mathrm{x}=0,5$ and 10 at. $\%)$ bulk metallic glasses (BMGs) were prepared, and the effect of the $\mathrm{Co} / \mathrm{Ni}$ elements substitution for Fe on the magnetocaloric properties of $\mathrm{Fe}_{80} \mathrm{P}_{13} \mathrm{C}_{7} \mathrm{BMG}$ has been investigated systematically. The Curie temperature $\left(T_{\mathrm{C}}\right)$ of the present Fe-based BMGs increases with the substitution of $\mathrm{Fe}$ by $\mathrm{Co} / \mathrm{Ni}$. The magnetic entropy change $\left(\Delta S_{M}\right)$ of the present Fe-based BMGs increases first and then decreases with the increase of Fe substituted by $\mathrm{Co}$, but monotonically decreases with the increase of Fe substituted by Ni. Among the present Fe-based BMGs, the $\mathrm{Fe}_{75} \mathrm{Co}_{5} \mathrm{P}_{13} \mathrm{C}_{7}$ BMG exhibits the maximum $\Delta S_{\mathrm{M}}$ value of $5.21 \mathrm{~J} \mathrm{~kg}^{-1} \mathrm{~K}^{-1}$ at an applied field of $5 \mathrm{~T}$, which is the largest value among Fe-based amorphous alloys without any rare earth elements reported so far. The present Fe-based BMGs exhibit the large glass forming ability, tunable $T_{C}$ and enhanced $\Delta S_{\mathrm{M}}$ value, which are beneficial for magnetic refrigerant materials.
\end{abstract}

Keywords: Fe-based bulk metallic glasses; Co/Ni substitution for Fe; magnetocaloric effect

\section{Introduction}

Compared with the traditional refrigeration technology of compressed gas medium, the magnetic refrigeration technology [1,2] is an environmentally friendly technology with high efficiency, low energy consumption and no environmental pollution $[3,4]$. Up to now, a series of the crystalline compounds, for example, Gd-Si-Ge [5,6], La-Fe-Si [7] and Mn-Fe-P-Ps [8], etc., show a giant magnetic entropy change $\left(\Delta S_{M}\right)$ based on the first order magnetic phase transition (FOMT), but also some shortcomings including the low corrosion resistance, high hysteresis losses and expensive raw materials, which greatly limit the application of these materials in the field of magnetic refrigeration [9,10]. Compared with the FOMT magnetocaloric materials, metallic glasses, e.g., Fe-based amorphous alloys, exhibit magnetocaloric effects based on the second order magnetic phase transition (SOMT) and possess the unique advantages of magnetic refrigeration materials, such as superior mechanical properties, low hysteresis and thermal hysteresis, higher electrical resistivity, and so on [11,12]. Moreover, Fe-based amorphous alloys show great potential for commercial use because of their abundant raw materials. However, Fe-based amorphous alloys show a low value of $\Delta S_{\mathrm{M}}$ frequently, which greatly restricts their application as magnetic refrigeration materials [13]. Therefore, it is of significance and importance for Fe-based amorphous alloys to improve magnetocaloric properties. 
Many studies have indicated that the element addition to Fe-based amorphous alloys may cause significant changes in their magnetocaloric properties. Usually, the rare earth elements are chosen to be a regulating element and are added into Fe-based amorphous alloys to improve magnetocaloric properties due to their large atomic magnetic moments. Recent studies show that minor additions of Gd or Dy elements increase the value of $\Delta S_{\mathrm{M}}$ while the excessive addition of $\mathrm{Gd}$ or Dy causes the value of $\Delta S_{\mathrm{M}}$ to decrease [14]. However, Ce element addition leads to the decrease of $\Delta S_{\mathrm{M}}$ [15] in Fe-Si-Nb-B-Cu metallic glasses. The addition of transition metals usually increases the $T_{C}$ and $\Delta S_{M}$ of Fe-based amorphous alloys due to the stronger atomic exchange interaction. The addition of $\mathrm{Cu}$ improves the magnetocaloric properties of Fe- $\mathrm{Zr}$ amorphous alloys [16]. The partial substitution of Fe by $\mathrm{Co}$ and $\mathrm{Ni}$ in Fe-Zr-B-Cu amorphous alloy leads to the increase of $T_{\mathrm{C}}$, and appropriate doping $\mathrm{Co}$ and $\mathrm{Ni}$ elements enhances the value of $\Delta S_{\mathrm{M}}$ for $\mathrm{Fe}_{71.5} \mathrm{Co}_{8.25} \mathrm{Ni}_{8.25} \mathrm{Zr}_{7} \mathrm{~B}_{4} \mathrm{Cu}_{1}$ amorphous alloy [17]. These results indicate that systematic investigation of the effect of transition metals on magnetocaloric effect should be significant.

Previous studies showed that $\mathrm{Fe}_{80} \mathrm{P}_{13} \mathrm{C}_{7}$ bulk metallic glass (BMG) exhibited excellent magnetocaloric performance with the $\Delta S_{\mathrm{M}}$ of $5.05 \mathrm{~J} \mathrm{~kg}^{-1} \mathrm{~K}^{-1}$ under an applied field of $5 \mathrm{~T}$ [18]. To further increase the $\Delta S_{\mathrm{M}}$ value of $\mathrm{Fe}_{80} \mathrm{P}_{13} \mathrm{C}_{7} \mathrm{BMG}$, the glass forming ability (GFA), magnetic properties and magnetocaloric performance of $\mathrm{Fe}_{80} \mathrm{P}_{13} \mathrm{C}_{7}$ BMG affected by partially substituting the transition metals $(\mathrm{Co} / \mathrm{Ni})$ for Fe were investigated systematically.

\section{Experiment}

$\mathrm{Fe}_{80-\mathrm{x}} \mathrm{M}_{\mathrm{x}} \mathrm{P}_{13} \mathrm{C}_{7}(\mathrm{M}=\mathrm{Co}, \mathrm{Ni} ; \mathrm{x}=0,5$ and 10 at.\%) alloy ingots were prepared by torchmelting the high purity elements $\mathrm{Fe}$ powders (99.9\% pure), $\mathrm{Fe}_{3} \mathrm{P}$ Powders $(99.5 \%$ pure), graphite powders (99.9\% pure), cobalt powders (99.9\% pure) and nickel powders $(99.7 \%$ pure) with a torch in a clean quartz tube under a high-purity argon atmosphere. The ingots were then placed into clean quartz tubes containing a fluxing agent of $\mathrm{B}_{2} \mathrm{O}_{3}$ and $\mathrm{CaO}$ powder (mass ratio $=3: 1$ ) and fluxed in a vacuum at 1150 degrees for $4 \mathrm{~h}$. After that, the glass alloy rods with a maximum diameter of $2.5 \mathrm{~mm}$ and a length of several centimeters were produced by the J-quenching technique [18].

The structure of the alloy rods was measured by Burker D8 advance X-ray diffrac-

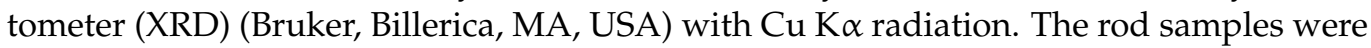
smashed to small pieces by a hammer before the XRD test to obtain the pattern with good quality. The thermal behavior of the glassy rod was estimated by NETZSCH DSC 404F1 differential scanning calorimetry (DSC) (NETZSCH, Selb, Germany) with a heating rate of $0.33 \mathrm{~K} / \mathrm{s}$ under an Ar atmosphere. The magnetic hysteresis loop of glassy rod samples was tested with the maximum applied field up to 10,000 Oe at the room temperature by a Lake Shore 7400 vibrating sample magnetometer (VSM) (Lake Shore, Carson, CA, USA). The field and temperature dependences of magnetization curves of the glassy rods were tested by Quantum Design ${ }^{\circledR}$ superconducting quantum interference device magnetometer (MPMS) (Quantum Design Int., San Diego, CA, USA), in which the measurement specimens were first cut about $3 \mathrm{~mm}$ from the bulk glassy rods with a diameter of $1 \mathrm{~mm}$ and then ground into rectangular slices with around $40 \mu \mathrm{m}$ thick and $1 \mathrm{~mm}$ width. The temperature interval is $10 \mathrm{~K}$ away from $T_{C}$ and $5 \mathrm{~K}$ near the $T_{C}$ in the isothermal magnetization curve measurements. The density of the samples was determined by Archimedes' method. Except for XRD test, the samples used in other tests are all $1 \mathrm{~mm}$ in diameter to avoid the risk of partial crystallization.

\section{Result and Discussion}

The XRD patterns of the as-cast $\mathrm{Fe}_{80-\mathrm{x}} \mathrm{M}_{\mathrm{x}} \mathrm{P}_{13} \mathrm{C}_{7}(\mathrm{M}=\mathrm{Co}, \mathrm{Ni} ; \mathrm{x}=0,5$ and 10 at.\%) alloy rods with the corresponding maximum diameters $\left(D_{\max }\right)$ for fully glass formation $[19,20]$ are shown in Figure 1. There are only typical halo peaks and no crystalline peaks in the XRD patterns of all the samples, verifying the fully glassy phase formation. Figure 2 shows the DSC curves of the as-cast glassy alloy rod specimen. All the curves show the sequential transition of the glass transition, supercooled liquid region and two-step crystallization. 
The DSC curves can further confirm the glassy structure of the present samples. With the substitution content of both Co and $\mathrm{Ni}$ for Fe increases from 0 to 10 at.\%, the $D_{\max }$ of the present Fe-based BMGs increases from 2.0 to $2.5 \mathrm{~mm}$, indicating that substituting Fe with a minor amount of $\mathrm{Co} / \mathrm{Ni}$ can increase the GFA of $\mathrm{Fe}_{80} \mathrm{P}_{13} \mathrm{C}_{7}$ alloy to a certain extent.

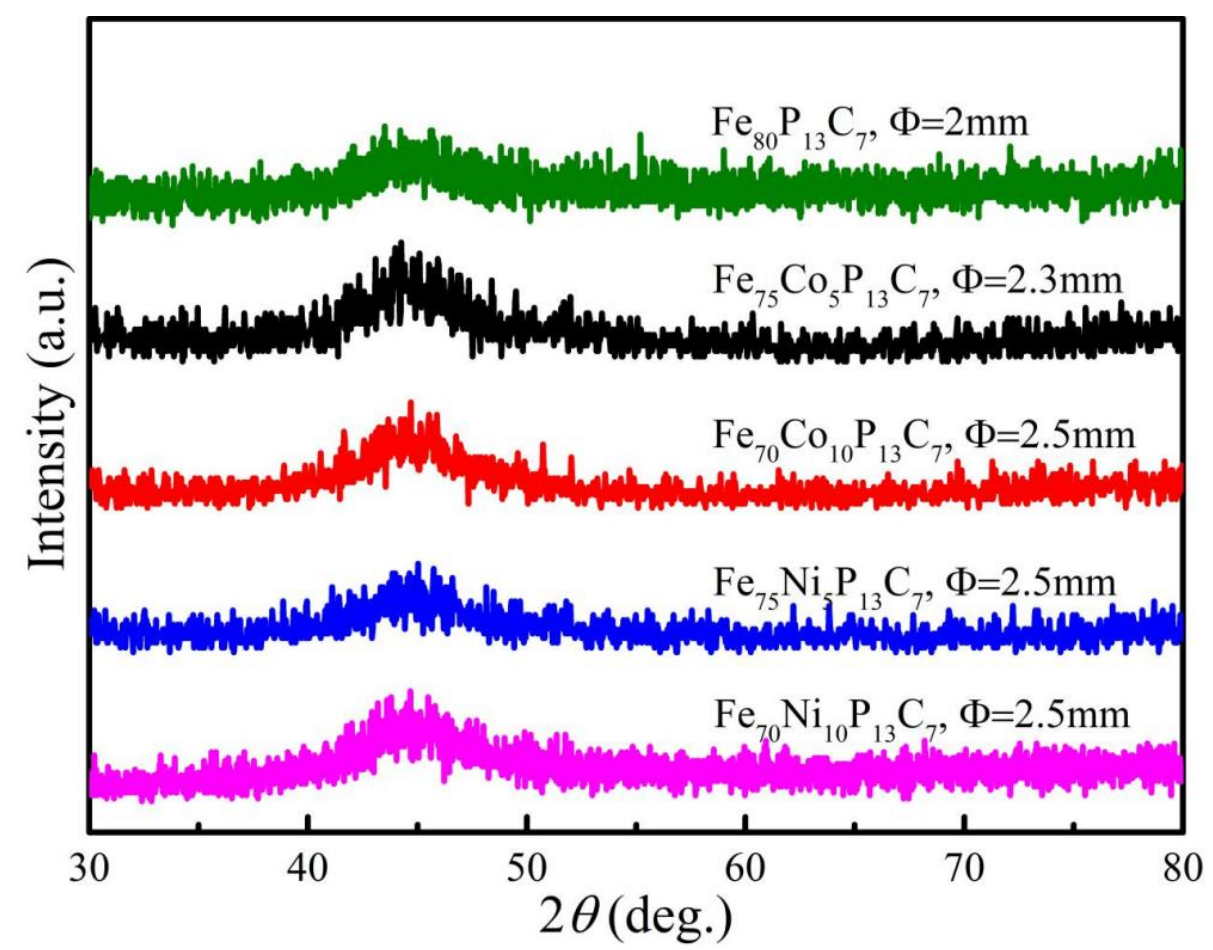

Figure 1. XRD patterns of the as-cast $\mathrm{Fe}_{80-\mathrm{x}} \mathrm{M}_{\mathrm{x}} \mathrm{P}_{13} \mathrm{C}_{7}(\mathrm{M}=\mathrm{Co}, \mathrm{Ni} ; \mathrm{x}=0,5$ and 10 at.\%) alloy rods with the corresponding maximum diameter for fully glass formation.

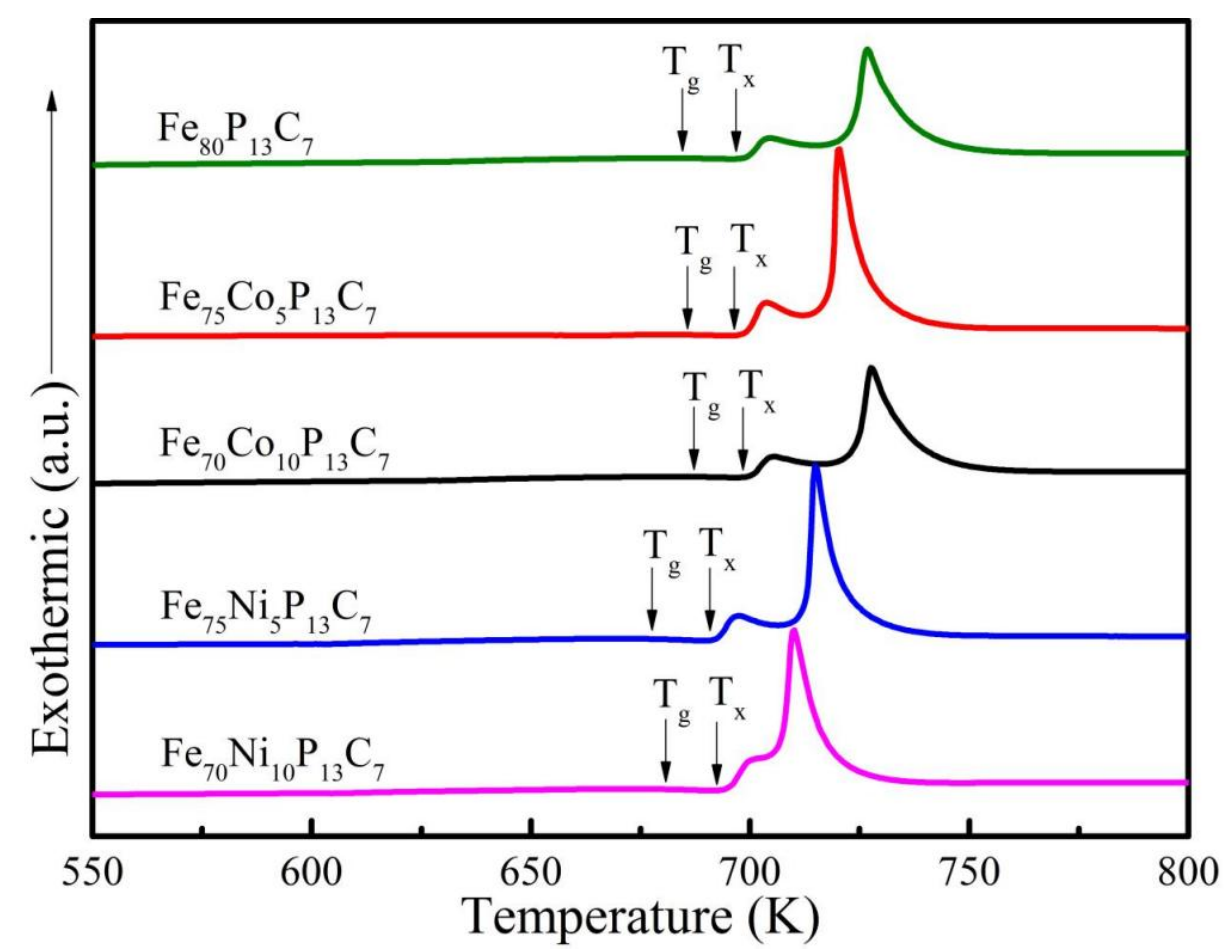

Figure 2. DSC curves of the as-cast $\mathrm{Fe}_{80-\mathrm{x}} \mathrm{M}_{\mathrm{x}} \mathrm{P}_{13} \mathrm{C}_{7}(\mathrm{M}=\mathrm{Co}, \mathrm{Ni} ; \mathrm{x}=0,5$ and 10 at. $\%)$ glassy alloy rods at a heating rate of $0.33 \mathrm{~K} / \mathrm{s}$. 
Figure 3 shows the hysteresis loops of the as-cast $\mathrm{Fe}_{80-\mathrm{x}} \mathrm{M}_{\mathrm{x}} \mathrm{P}_{13} \mathrm{C}_{7}(\mathrm{M}=\mathrm{Co}, \mathrm{Ni} ; \mathrm{x}=0$, 5 and 10 at.\%) glassy rods tested by VSM, and the determined saturation magnetization $\left(J_{s}\right)$ of the measured samples are shown in Table 1. All the glassy rod samples show good soft magnetic performance and low coercivity. The $J_{S}$ of the glassy rod samples firstly increases from 160 to $165 \mathrm{emu} / \mathrm{g}$ with the increase of Co substituting for Fe from 0 to 5 at.\%, and then decreases to $157 \mathrm{emu} / \mathrm{g}$ when the Co content reaches 10 at.\%, while the $J_{s}$ value monotonically decreases from 160 to $150 \mathrm{emu} / \mathrm{g}$ with the Ni substitution for Fe increases from 0 to 10 at. $\%$.

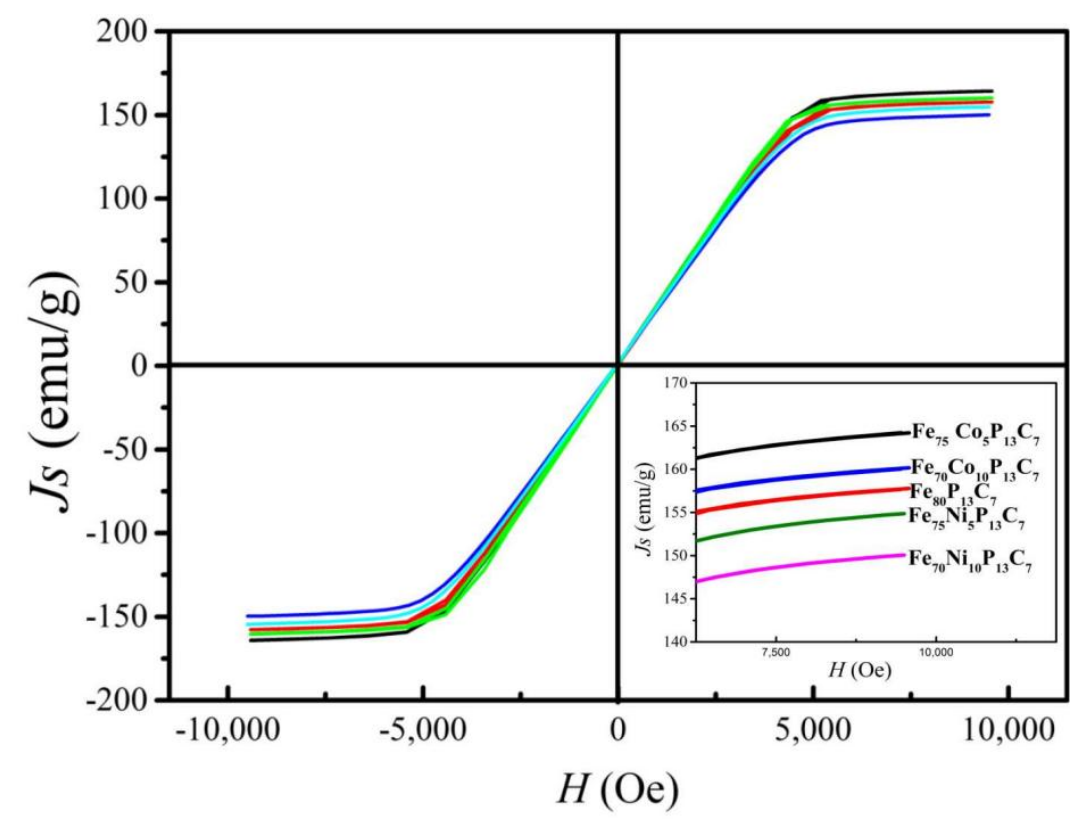

Figure 3. The hysteresis loops of the as-cast $\mathrm{Fe}_{80-\mathrm{x}} \mathrm{M}_{\mathrm{x}} \mathrm{P}_{13} \mathrm{C}_{7}(\mathrm{M}=\mathrm{Co}, \mathrm{Ni} ; \mathrm{x}=0,5$ and 10 at.\%) glassy alloy rods at room temperature and the inset is the enlarged part of the magnetization curve.

Table 1. The maximum diameter for fully glass formation $\left(D_{\max }\right)$, magnetic transition temperature $\left(T_{\mathrm{C}}\right)$, the saturation magnetization $\left(J_{s}\right)$ and magnetocaloric properties at the magnetic applied field of $1.5 \mathrm{~T}$ and $5 \mathrm{~T}$ for the present $\mathrm{Fe}_{80-\mathrm{x}} \mathrm{M}_{\mathrm{x}} \mathrm{P}_{13} \mathrm{C}_{7}$ $(\mathrm{M}=\mathrm{Co}, \mathrm{Ni} ; \mathrm{x}=0,5$ and 10 at. $\%)$ BMGs.

\begin{tabular}{|c|c|c|c|c|c|c|c|c|}
\hline \multirow{2}{*}{$\begin{array}{l}\text { Composition } \\
\text { (at.\%) }\end{array}$} & \multirow{2}{*}{$\begin{array}{l}D_{\max } \\
(\mathrm{mm})\end{array}$} & \multirow{2}{*}{$\begin{array}{l}T_{\mathrm{C}} \\
(\mathrm{K})\end{array}$} & \multirow{2}{*}{$\begin{array}{c}J_{s} \\
(\mathrm{emu} / \mathrm{g})\end{array}$} & \multicolumn{2}{|c|}{$\begin{array}{c}-\Delta S_{\mathrm{M}} \\
\left(\mathrm{Jg}^{-1} \mathrm{~K}^{-1}\right)\end{array}$} & \multirow{2}{*}{$\begin{array}{c}\Delta T_{\text {FWHM }} \\
(\mathrm{K})\end{array}$} & \multicolumn{2}{|c|}{$\begin{array}{c}R C_{\mathrm{FWHM}} \\
\left(\mathrm{J} \mathrm{kg}^{-1}\right)\end{array}$} \\
\hline & & & & $1.5 \mathrm{~T}$ & $5 \mathrm{~T}$ & & $1.5 \mathrm{~T}$ & $5 \mathrm{~T}$ \\
\hline $\mathrm{Fe}_{80} \mathrm{P}_{13} \mathrm{C}_{7}$ & 2.0 & 581 & 160 & 2.20 & 5.05 & 57.1 & 125.6 & 479.8 \\
\hline $\mathrm{Fe}_{75} \mathrm{Co}_{5} \mathrm{P}_{13} \mathrm{C}_{7}$ & 2.3 & 623 & 165 & 2.34 & 5.21 & 39.1 & 91.6 & 331.6 \\
\hline $\mathrm{Fe}_{70} \mathrm{Co}_{10} \mathrm{P}_{13} \mathrm{C}_{7}$ & 2.5 & 649 & 157 & 2.08 & 4.98 & 55.4 & 115.2 & 462.1 \\
\hline $\mathrm{Fe}_{75} \mathrm{Ni}_{5} \mathrm{P}_{13} \mathrm{C}_{7}$ & 2.5 & 596 & 155 & 2.04 & 4.60 & 52.2 & 106.5 & 381.8 \\
\hline $\mathrm{Fe}_{70} \mathrm{Ni}_{10} \mathrm{P}_{13} \mathrm{C}_{7}$ & 2.5 & 600 & 150 & 1.46 & 3.26 & 48.7 & 71.1 & 211.2 \\
\hline
\end{tabular}

Figure $4 \mathrm{a}$ shows that the temperature varies with magnetization $(M-T$ curve) of the as-cast $\mathrm{Fe}_{80-\mathrm{x}} \mathrm{M}_{\mathrm{x}} \mathrm{P}_{13} \mathrm{C}_{7}(\mathrm{M}=\mathrm{Co}, \mathrm{Ni} ; \mathrm{x}=0,5$ and 10 at.\%) glassy rod samples tested by MPMS at a magnetic applied field of $0.02 \mathrm{~T}$, and Figure $4 \mathrm{~b}$ shows the $T_{C}$ determined by the differentiation of $M-T$ curves and summarized in Table 1 . It can be concluded that with the increase of $\mathrm{Co} / \mathrm{Ni}$ substituting $\mathrm{Fe}$, the $T_{C}$ of Fe-based BMGs increases, and further the rise rate of $T_{C}$ with the Co content is greater than that with the Ni content. Based on the mean field theory, $T_{C}$ is proportionate to the saturation magnetization and the exchange integral, in which the exchange integral is dependent on the distance between magnetic atoms [21]. The radii of $\mathrm{Fe}, \mathrm{Co}$ and $\mathrm{Ni}$ atoms are $0.124 \mathrm{~nm}, 0.125 \mathrm{~nm}$ and $0.125 \mathrm{~nm}$, respectively [22]. Therefore, based on the Bathe-Slater curve [21], the replacement of $\mathrm{Co} / \mathrm{Ni}$ for part of Fe caused a stronger atomic exchange interaction, and thus the higher $T_{C}$. 

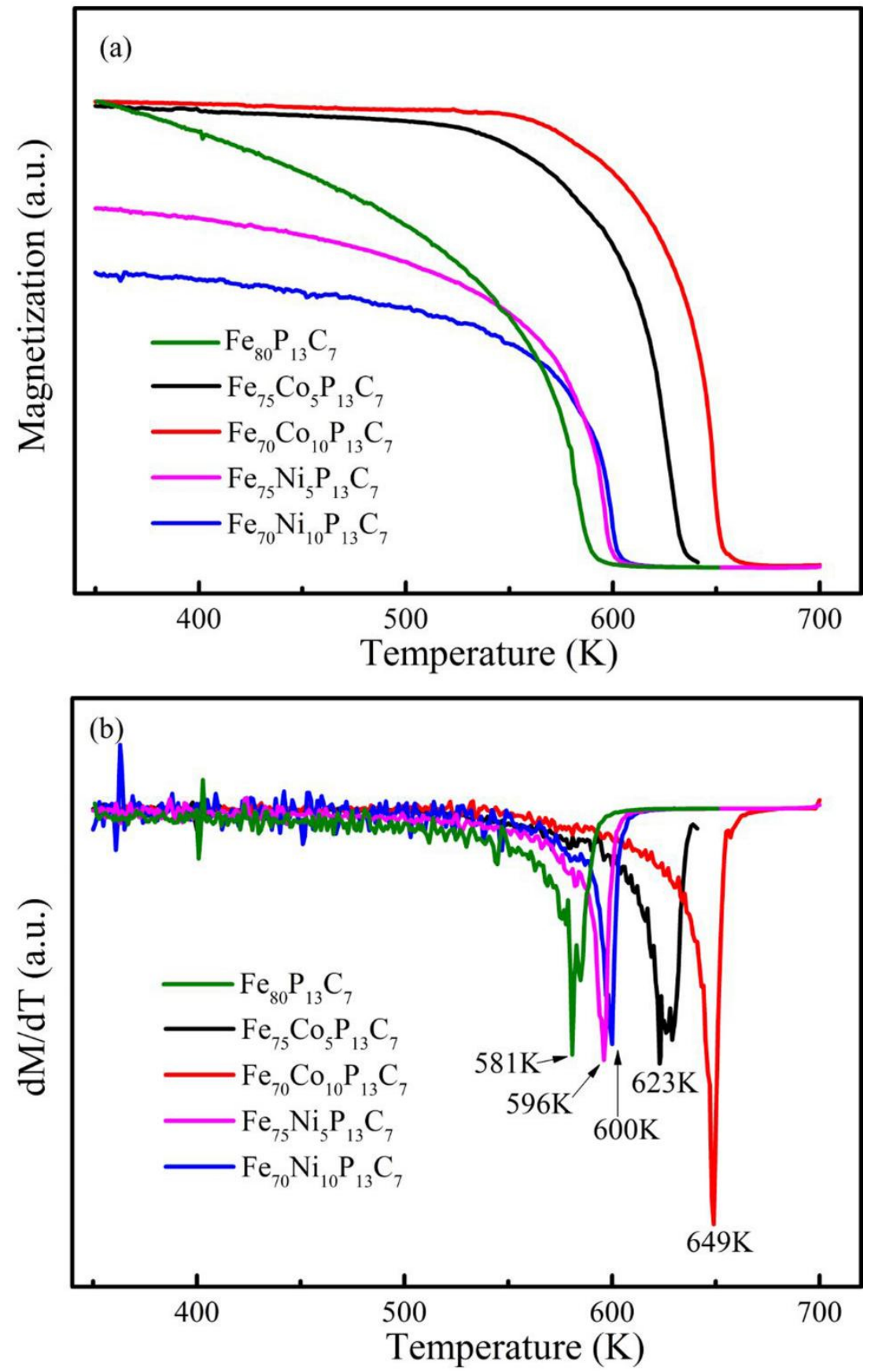

Figure 4. Temperature varies with magnetization (a) and $d M / d T$ (b) of as-cast $\mathrm{Fe}_{80-\mathrm{x}} \mathrm{M}_{\mathrm{x}} \mathrm{P}_{13} \mathrm{C}_{7}$ $(\mathrm{M}=\mathrm{Co}, \mathrm{Ni} ; \mathrm{x}=0,5$ and 10 at. $\%)$ glassy alloy rod samples.

The isothermal magnetization curves of the $\mathrm{Fe}_{80-\mathrm{x}} \mathrm{M}_{\mathrm{x}} \mathrm{P}_{13} \mathrm{C}_{7}(\mathrm{M}=\mathrm{Co}, \mathrm{Ni} ; \mathrm{x}=0,5$ and 10 at.\%) glassy alloy rod samples at the magnetic applied fields of 1.5 to $5 \mathrm{~T}$ are shown in Figure 5. When the test temperature is below $T_{C}$, the samples reach the magnetization saturation under low applied magnetic fields, but when the temperature gets close to or above $T_{C}$, the $M-H$ curves of the samples become linear, indicating that the samples turn from ferromagnetic to paramagnetic state [23]. 

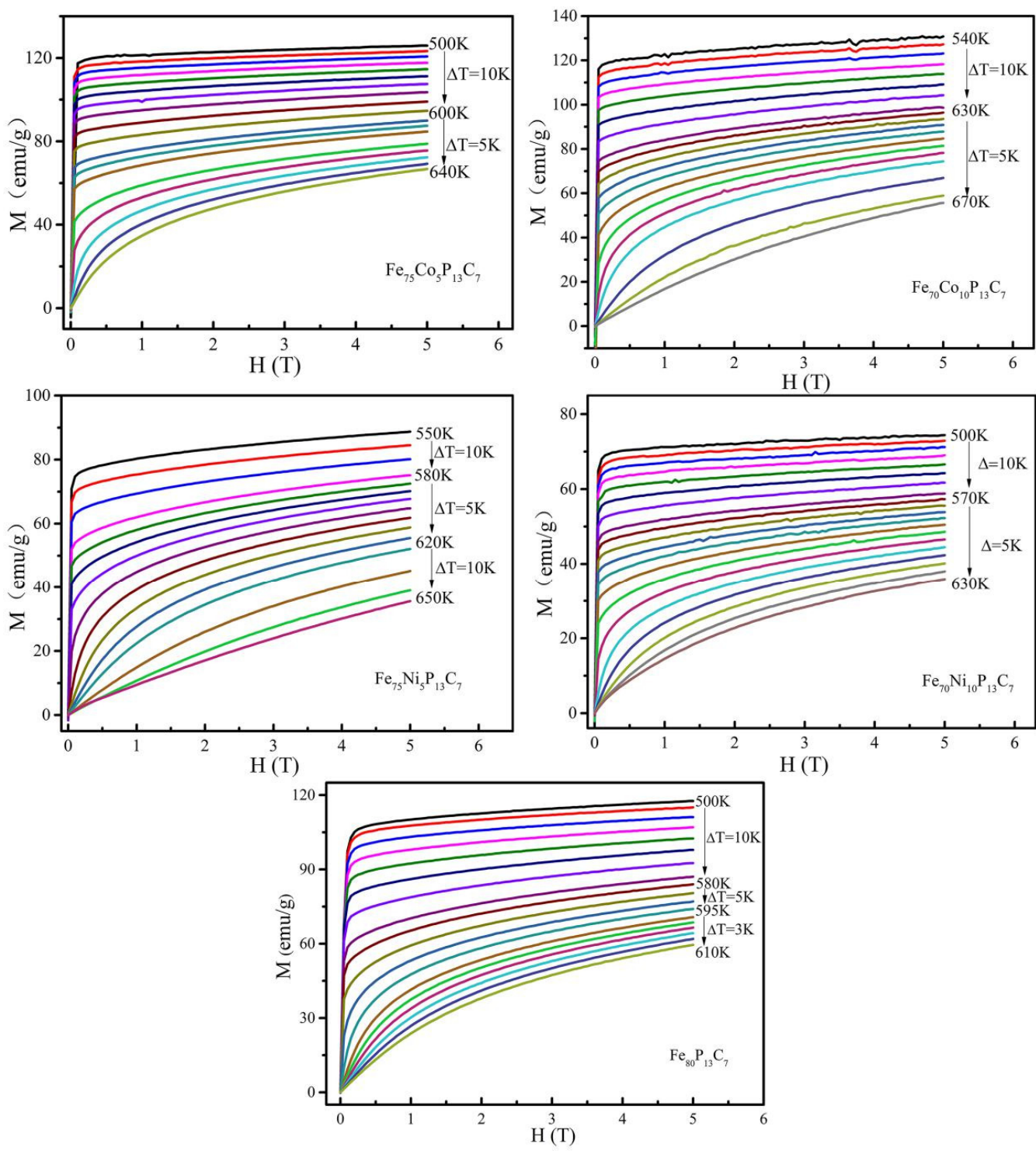

Figure 5. The isothermal magnetization curves of $\mathrm{Fe}_{80-\mathrm{x}} \mathrm{M}_{\mathrm{x}} \mathrm{P}_{13} \mathrm{C}_{7}(\mathrm{M}=\mathrm{Co}, \mathrm{Ni} ; \mathrm{x}=0,5$ and 10 at. $\%)$ glassy alloy rods at the magnetic applied fields up to $5 \mathrm{~T}$.

In most research on characterization of magnetocaloric materials, the magnetic entropy change $\left(\Delta S_{\mathrm{M}}\right)$ is an important parameter and $\Delta S_{\mathrm{M}}$ under the applied maximum magnetic field of $H_{\max }$ is defined as the follow equation [3,24]:

$$
\Delta S_{\mathrm{M}}=\int_{0}^{H_{\max }}\left(\frac{\partial M}{\partial T}\right)_{H} d H
$$

where $M$ is the magnetization under the applied magnetic field of $H$. Equation (1) can also be written in other terms:

$$
\Delta S_{\mathrm{M}}\left(T_{i}, H_{\text {max }}\right)=\frac{\int_{0}^{H_{\max }} M\left(T_{i}, H\right) d H-\int_{0}^{H_{\max }} M\left(T_{i+1}, H\right) d H}{T_{i}-T_{i+1}}
$$

where $M\left(T_{i}, H\right)$ and $M\left(T_{i+1}, H\right)$ are the magnetization at the temperature of $T_{i}$ and $T_{i+1}$, respectively, and under the applied magnetic field of $H$. Based on the $\mathrm{M}-\mathrm{H}$ curves of the samples at different temperature in Figure 6, the change of $-\Delta S_{M}$ with temperature of $\mathrm{Fe}_{80-\mathrm{x}} \mathrm{M}_{\mathrm{x}} \mathrm{P}_{13} \mathrm{C}_{7}(\mathrm{M}=\mathrm{Co}, \mathrm{Ni} ; \mathrm{x}=0,5$ and 10 at.\%) glassy rod samples under the different applied maximum fields can be constructed according to Formula (2) and is shown in 
Figure 6, and the peak values $\left(\left|\Delta S_{\mathrm{M}}^{\text {peak }}\right|\right)$ determined from the $\Delta S_{\mathrm{M}}-T$ curve of the samples under the applied field of $1.5 \mathrm{~T}$ and $5.0 \mathrm{~T}$ are summarized in Table 1. The $\left|\Delta S_{\mathrm{M}}^{\text {peak }}\right|$ values of $\mathrm{Fe}_{80} \mathrm{P}_{13} \mathrm{C}_{7}, \mathrm{Fe}_{75} \mathrm{Co}_{5} \mathrm{P}_{13} \mathrm{C}_{7}, \mathrm{Fe}_{70} \mathrm{Co}_{10} \mathrm{P}_{13} \mathrm{C}_{7}, \mathrm{Fe}_{75} \mathrm{Ni}_{5} \mathrm{P}_{13} \mathrm{C}_{7}$ and $\mathrm{Fe}_{70} \mathrm{Ni}_{10} \mathrm{P}_{13} \mathrm{C}_{7}$ are 2.20, 2.34, $2.08,2.04$ and $1.46 \mathrm{~J} \mathrm{~kg}^{-1} \mathrm{~K}^{-1}$ at an applied field of $1.5 \mathrm{~T}$, respectively, and 5.05, 5.21, $4.98,4.60$ and $3.26 \mathrm{~J} \mathrm{~kg}^{-1} \mathrm{~K}^{-1}$ at an applied field of $5.0 \mathrm{~T}$, respectively. Compared to the $\mathrm{Fe}_{80} \mathrm{P}_{13} \mathrm{C}_{7}$ BMG, replacing 5 at. $\%$ of Fe by Co increases the value of $\left|\Delta S_{\mathrm{M}}^{\text {peak }}\right|$ while 10 at.\% substitution of Co for Fe reduces the value of $\left|\Delta S_{\mathrm{M}}^{\text {peak }}\right|$; the value of $\left|\Delta S_{\mathrm{M}}^{\text {peak }}\right|$ continuously decreases with the increasing of Ni substituted for Fe content. It can be found that the changing trend of $\left|\Delta S_{\mathrm{M}}^{\text {peak }}\right|$ value is consistent with that of $J_{s}$ value with the substitution of $\mathrm{Co} / \mathrm{Ni}$ for Fe in the present Fe-based BMGs. Many studies [24] have pointed out that there is a positive correlation between the $J_{s}$ of magnetic materials and the $\left|\Delta S_{\mathrm{M}}^{\text {peak }}\right|$. The $\left|\Delta S_{\mathrm{M}}^{\text {peak }}\right|$ as a function of $J_{s}$ for the present $\mathrm{Fe}_{80-\mathrm{x}} \mathrm{M}_{\mathrm{x}} \mathrm{P}_{13} \mathrm{C}_{7}(\mathrm{M}=\mathrm{Co}, \mathrm{Ni} ; \mathrm{x}=0,5$ and 10 at.\%) BMGs at the magnetic applied field of $1.5 \mathrm{~T}$ and $5.0 \mathrm{~T}$ are shown in Figure 7 , in which the good linear relationship with the R-square value of 0.864 , indicates that the present Fe-based BMGs follow this correlation relationship.
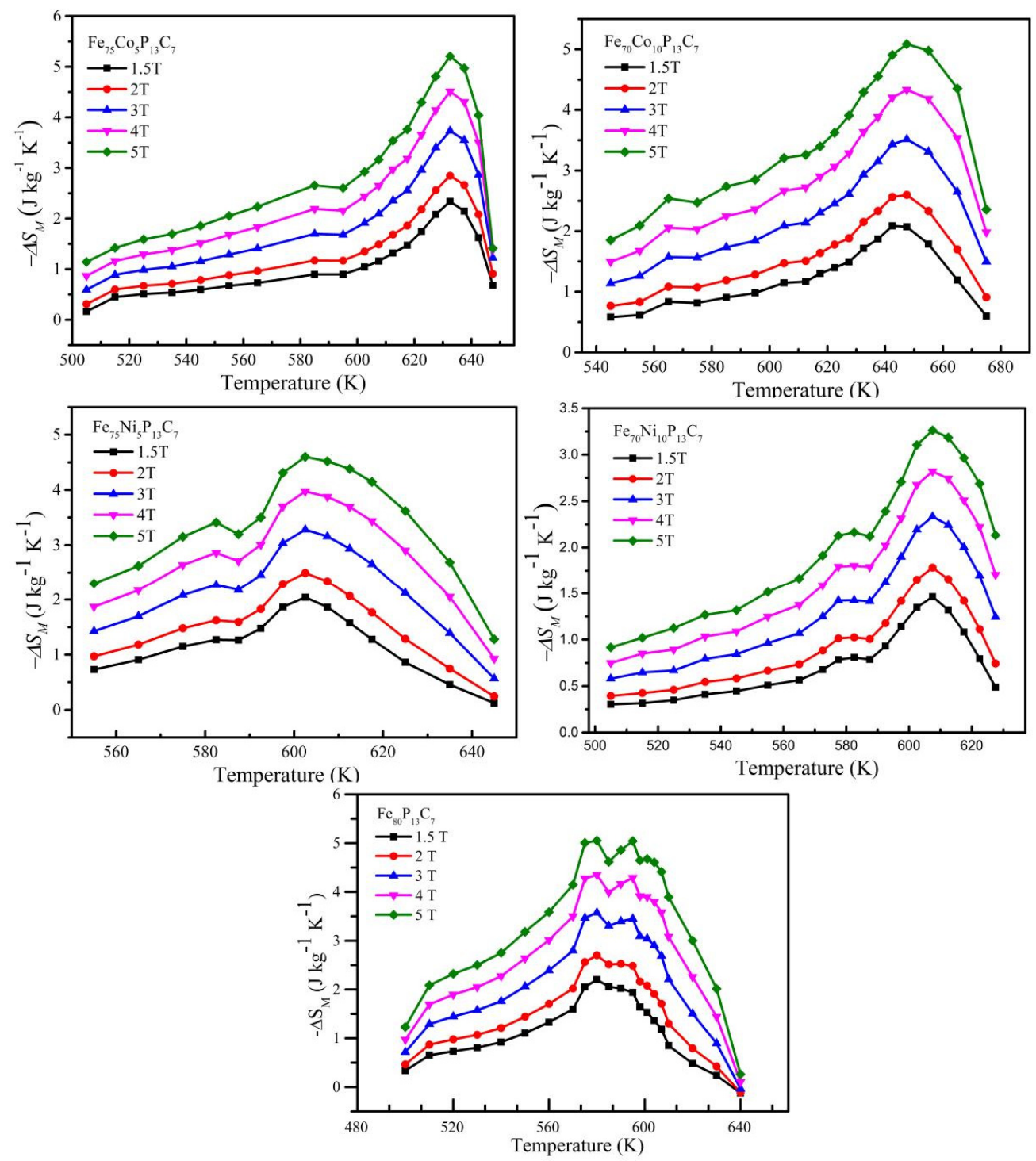

Figure 6. Magnetic entropy changes as a function of temperature under 1.5-5 T for $\mathrm{Fe}_{80-\mathrm{x}} \mathrm{M}_{\mathrm{x}} \mathrm{P}_{13} \mathrm{C}_{7}$ $(\mathrm{M}=\mathrm{Co}, \mathrm{Ni} ; \mathrm{x}=0,5$ and 10 at. $\%)$ glassy alloy rods. 


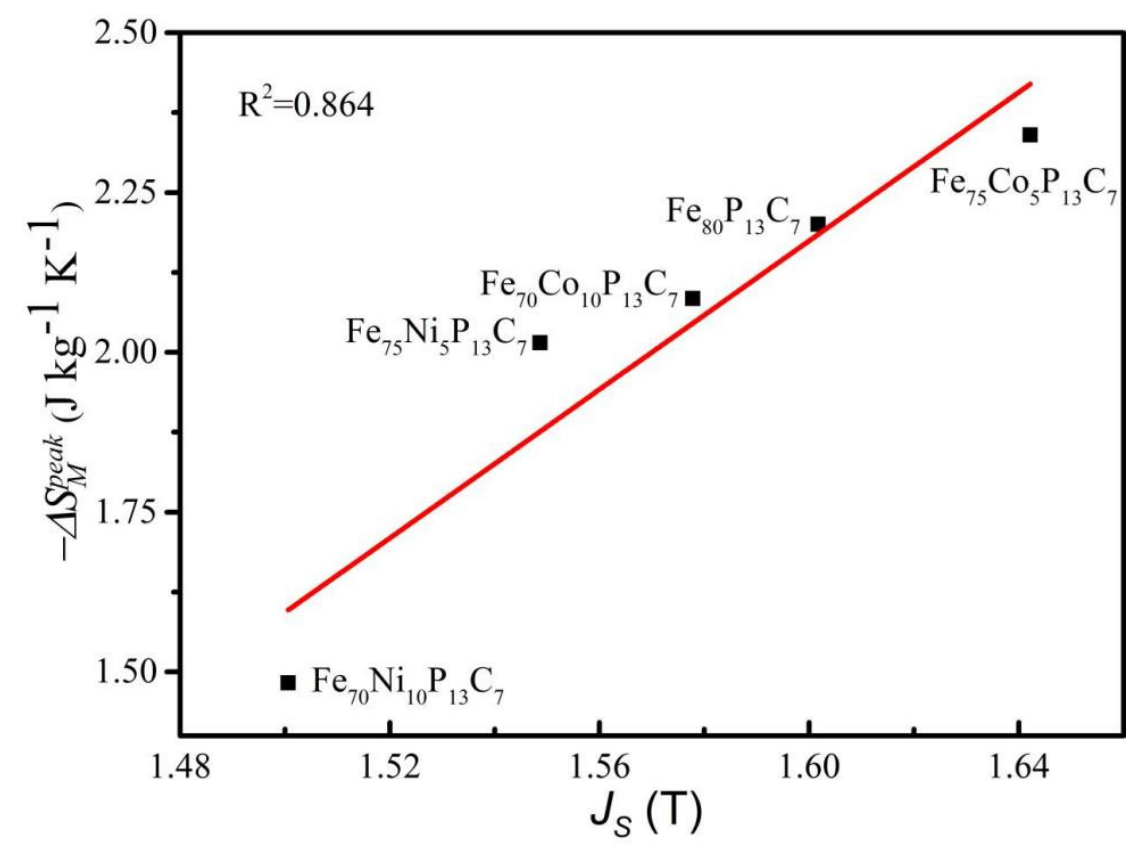

Figure 7. The relationship between saturation magnetization $\left(J_{s}\right)$ at room temperature and the maximum magnetic entropy changes $\left(\left|\Delta S_{\mathrm{M}}^{\text {peak }}\right|\right)$ of $\mathrm{Fe}_{80-\mathrm{x}} \mathrm{M}_{\mathrm{x}} \mathrm{P}_{13} \mathrm{C}_{7}(\mathrm{M}=\mathrm{Co}, \mathrm{Ni} ; \mathrm{x}=0,5$ and 10 at.\%) glassy alloy rods at a magnetic applied field of $1.5 \mathrm{~T}$.

Another important parameter that is often applied for the characterization of magnetocaloric effect is refrigeration capacity $(R C)$, which equals to the area of the $\Delta S_{M}-T$ curve. The $R C_{F W H M}$ can be obtained by the following equation $[17,25]$ :

$$
R C_{F W H M}=-\Delta S_{M}^{\text {peak }} \times \Delta T_{F W H M}
$$

where $\Delta T_{F W H M}$ is the temperature interval corresponding to the half-width of the $\Delta S_{\mathrm{M}}-$ $T$ curve. The $\Delta T_{F W H M}$ and $R C_{F W H M}$ values of each glassy rod samples are listed in Table 1. We can see that the $R C_{F W H M}$ of the $\mathrm{Fe}_{80} \mathrm{P}_{13} \mathrm{C}_{7}, \mathrm{Fe}_{75} \mathrm{Co}_{5} \mathrm{P}_{13} \mathrm{C}_{7}, \mathrm{Fe}_{70} \mathrm{Co}_{10} \mathrm{P}_{13} \mathrm{C}_{7}, \mathrm{Fe}_{75} \mathrm{Ni}_{5} \mathrm{P}_{13} \mathrm{C}_{7}$, $\mathrm{Fe}_{70} \mathrm{Ni}_{10} \mathrm{P}_{13} \mathrm{C}_{7}$ glassy rods are $125.6,91.6,115.2,106.5,71.1 \mathrm{~J} \mathrm{~kg}^{-1}$ under $1.5 \mathrm{~T}$, respectively. It is worth noting that, compared with the $\mathrm{Fe}_{80} \mathrm{P}_{13} \mathrm{C}_{7} \mathrm{BMG}$, the $\mathrm{Fe}_{80-\mathrm{x}} \mathrm{Co}_{\mathrm{x}} \mathrm{P}_{13} \mathrm{C}_{7} \mathrm{BMG}$ shows the larger $\left|\Delta S_{\mathrm{M}}^{\text {peak }}\right|$ but smaller $R C_{F W H M}$, which is attributed to the smaller $\Delta T_{F W H M}$ of the $\mathrm{Fe}_{75} \mathrm{Co}_{5} \mathrm{P}_{13} \mathrm{C}_{7} \mathrm{BMG}$, as shown in Table 1 . The smaller $\Delta T_{F W H M}$ is presumably the stronger magnetic coupling in the $\mathrm{Fe}_{75} \mathrm{Co}_{5} \mathrm{P}_{13} \mathrm{C}_{7} \mathrm{BMG}$.

\section{Conclusions}

In this work, the $\mathrm{Fe}_{80-\mathrm{x}} \mathrm{M}_{\mathrm{x}} \mathrm{P}_{13} \mathrm{C}_{7}(\mathrm{M}=\mathrm{Co}, \mathrm{Ni} ; \mathrm{x}=0,5$ and 10 at.\%) bulk glassy rods are fabricated by combining fluxing treatment and the J-quenching technique. Moreover, their magnetocaloric properties are investigated. The replacement of $\mathrm{Co} / \mathrm{Ni}$ for Fe caused the increase of $T_{C}$ from $579 \mathrm{~K}$ for $\mathrm{x}=0$ to $649 \mathrm{~K}$ for $\mathrm{M}=\mathrm{Co}, \mathrm{x}=10$ and $600 \mathrm{~K}$ for $\mathrm{M}=\mathrm{Ni}$, $\mathrm{x}=10$. The $\left|\Delta S_{\mathrm{M}}^{\mathrm{peak}}\right|$ and $R C_{F W H M}$ values of $\mathrm{Fe}_{80} \mathrm{P}_{13} \mathrm{C}_{7}, \mathrm{Fe}_{75} \mathrm{Co}_{5} \mathrm{P}_{13} \mathrm{C}_{7}, \mathrm{Fe}_{70} \mathrm{Co}_{10} \mathrm{P}_{13} \mathrm{C}_{7}$, $\mathrm{Fe}_{75} \mathrm{Ni}_{5} \mathrm{P}_{13} \mathrm{C}_{7}, \mathrm{Fe}_{70} \mathrm{Ni}_{10} \mathrm{P}_{13} \mathrm{C}_{7}$ are 5.05, 5.21, 4.98, 4.60, $3.26 \mathrm{~J} \mathrm{~kg}^{-1} \mathrm{~K}^{-1}$, and 479.8, 331.6, $462.1,381.8,211.2 \mathrm{~J} \mathrm{~kg}^{-1}$, respectively, at the magnetic applied field of $5 \mathrm{~T}$. Significantly, the $\mathrm{Fe}_{75} \mathrm{Co}_{5} \mathrm{P}_{13} \mathrm{C}_{7}$ amorphous alloy exhibits the largest value of $\left|\Delta S_{\mathrm{M}}^{\text {peak }}\right|$ in the Fe-based amorphous alloys without any rare earth elements as reported so far. The high $T_{C}$ of the present BMGs may limit their application but can be lowered to room temperature by adding some selected elements, which makes them possible for room temperature magnetic refrigeration. 
Author Contributions: Conceptualization, J.G. and Q.L.; formal analysis, J.G.; investigation, J.G. and L.X.; resources, L.X., Q.L., J.H. and X.M.; writing-original draft preparation, J.G.; writing-review and editing, C.L., Q.L., J.H., C.C., H.L. and X.M.; funding acquisition, Q.L. and H.L. All authors have read and agreed to the published version of the manuscript.

Funding: This research was funded by National Natural Science Foundation of China, grant number 51771161; the Leading Talents of Tianshan Cedar Program of Xinjiang Uygur Autonomous Region, grant number 2019XS02; the Tianshan Innovation Team Program of Xinjiang Uygur Autonomous Region, grant number 2020D14038; and the financial support from Beijing Municipal Natural Science Foundation, grant number 2202033.

Institutional Review Board Statement: Not applicable.

Informed Consent Statement: Not applicable.

Data Availability Statement: Not applicable.

Acknowledgments: This research was supported by National Natural Science Foundation of China (No. 51771161), the Leading Talents of Tianshan Cedar Program of Xinjiang Uygur Autonomous Region (No. 2019XS02), and the Tianshan Innovation Team Program of Xinjiang Uygur Autonomous Region (No. 2020D14038). The author (Hongxiang Li) appreciates the financial support from Beijing Municipal Natural Science Foundation (No. 2202033).

Conflicts of Interest: The authors declare no conflict of interest.

\section{References}

1. Franco, V.; Blázquez, J.S.; Ingale, A.; Conde, B. The magnetocaloric effect and magnetic refrigeration near room temperature: Materials and models. Annu. Rev. Mater. Res. 2012, 42, 305-342. [CrossRef]

2. Gutfleisch, O.; Willard, M.A.; Brück, E.; Chen, C.H.; Sankar, S.G.; Liu, J.P. Magnetic materials and devices for the 21st century: Stronger, lighter, and more energy efficient. Adv. Mater. 2011, 23, 821-842. [CrossRef] [PubMed]

3. Phan, M.-H.; Yu, S.-C. Review of the magnetocaloric effect in manganite materials. J. Magn. Magn. Mater. 2007, 308, 325-340. [CrossRef]

4. Tishin, A.M.; Spichkin, Y.I. The Magnetocaloric Effect and Its Applications, 1st ed.; Institute of Physics: London, UK, 2003.

5. Alves, C.S.; Gama, S.; Coelho, A.D.A.; Plaza, E.J.R.; Carvalho, A.M.G.; Cardoso, L.P.; Persiano, A.C. Giant magnetocaloric effect in $\mathrm{Gd}_{5}\left(\mathrm{Si}_{2} \mathrm{Ge}_{2}\right)$ alloy with low purity Gd. Mater. Res. Mater. Res. 2004, 7, 535-538. [CrossRef]

6. Kimel, A.V.; Kirilyuk, A.; Tsvetkov, A.; Pisarev, R.V.; Rasing, T. Laser-induced ultrafast spin reorientation in the antiferromagnet $\mathrm{TmFeO}_{3}$. Nature 2004, 429, 850-853. [CrossRef] [PubMed]

7. Liu, J.; Moore, J.D.; Skokov, K.P.; Krautz, M.; Löwe, K.; Barcza, A.; Katter, M.; Gutfleisch, O. Exploring La (Fe,Si) 13 -based magnetic refrigerants towards application. Scr. Mater. 2012, 67, 584-589. [CrossRef]

8. Tegus, O.; Brück, E.; Buschow, K.H.J.; De Boer, F.R. Transition-metal-based magnetic refrigerants for room-temperature applications. Nat. Cell Biol. 2002, 415, 150-152. [CrossRef]

9. Li, X.; Pan, Y. Magnetocaloric effect in Fe-Zr-B-M (M=Ni, Co, Al, and Ti) amorphous alloys. J. Appl. Phys. 2014, 116, 093910. [CrossRef]

10. Wang, Y.F.; Qin, F.X.; Wang, Y.H.; Wang, H.; Das, R.; Phan, M.H.; Peng, H.X. Magnetocaloric effect of Gd-based microwires from binary to quaternary system. AIP Adv. 2017, 7, 056422. [CrossRef]

11. Wang, W. The nature and properties of amorphous materials. Prog. Phys. 2013, 33, 177-350.

12. Wang, F.; Inoue, A.; Han, Y. Excellent soft magnetic Fe-Co-B-based amorphous alloys with extremely high saturation magnetization above 1.85 T and low coercivity below $3 \mathrm{~A} / \mathrm{m}$. J. Alloys Compd. 2017, 711, 132-142. [CrossRef]

13. Zhang, H.; Li, R.; Xu, T.; Liu, F.; Zhang, T. Near room-temperature magnetocaloric effect in FeMnPBC metallic glasses with tunable Curie temperature. J. Magn. Magn. Mater. 2013, 347, 131-135. [CrossRef]

14. Zhao, L.; Tian, H.; Zhong, X.; Liu, Z.; Greneche, J.M.; Ramanujan, R.V. Influence of gadolinium and dysprosium substitution on magnetic properties and magnetocaloric effect of $\mathrm{Fe}_{78-\mathrm{x}} \mathrm{RE}_{\mathrm{x}} \mathrm{Si}_{4} \mathrm{Nb}_{5} \mathrm{~B}_{12} \mathrm{Cu}_{1}$ amorphous alloys. J. Rare Earths 2020, 38, 1317-1321. [CrossRef]

15. Tian, H.; Zhong, X.; Liu, Z.; Zheng, Z.; Min, J.X. Achieving table-like magnetocaloric effect and large refrigerant capacity around room temperature in $\mathrm{Fe}_{78-\mathrm{x}} \mathrm{Ce}_{\mathrm{x}} \mathrm{Si}_{4} \mathrm{Nb}_{5} \mathrm{~B}_{12} \mathrm{Cu}_{1}(\mathrm{x}=0-10)$ composite materials. Mater. Lett. 2015, 138, 64-66. [CrossRef]

16. Yang, W.; Li, W.; Wan, C.; Huo, J.; Mo, J.; Liu, H.; Shen, B. Low-temperature magnetic properties and magnetocaloric effect of Fe-Zr-Cu amorphous alloys. J. Low Temp. Phys. 2020, 200, 51-61. [CrossRef]

17. Caballero-Flores, R.; Franco, V.; Conde, A.; Knipling, K.E.; Willard, M.A. Influence of Co and Ni addition on the magnetocaloric effect in $\mathrm{Fe}_{88-2 \mathrm{x}} \mathrm{Co}_{x} \mathrm{Ni}_{\mathrm{x}} \mathrm{Zr}_{7} \mathrm{~B}_{4} \mathrm{Cu}_{1}$ soft magnetic amorphous alloys. Appl. Phys. Lett. 2010, 96, 182506. [CrossRef]

18. Yang, W.; Huo, J.; Liu, H.; Li, J.; Song, L.; Li, Q.; Xue, L.; Shen, B.; Inoue, A. Extraordinary magnetocaloric effect of Fe-based bulk glassy rods by combining fluxing treatment and J-quenching technique. J. Alloys Compd. 2016, 684, 29-33. [CrossRef] 
19. Xu, K.; Ling, H.; Li, Q.; Li, J.; Yao, K.; Guo, S. Effects of Co substitution for Fe on the glass forming ability and properties of $\mathrm{Fe}_{80} \mathrm{P}_{13} \mathrm{C}_{7}$ bulk metallic glasses. Intermetallics 2014, 51, 53-58. [CrossRef]

20. Ma, X.H.; Zhang, L.; Yang, X.H.; Li, Q.; Huang, Y.D. Effect of Ni addition on corrosion resistance of FePC bulk glassy alloy. Corros. Eng. Sci. Technol. 2014, 50, 433-437. [CrossRef]

21. Cullity, B.D.; Graham, C.D. Introduction to Magnetic Materials, 2nd ed.; John Wiley \& Sons: Hoboken, NJ, USA, 2009.

22. Takeuchi, A.; Inoue, A. Classification of bulk metallic glasses by atomic size difference, heat of mixing and period of constituent elements and its application to characterization of the main alloying element. Mater. Trans. 2005, 46, 2817-2829. [CrossRef]

23. Kucuk, I.; Şarlar, K.; Adam, A.; Civan, E. Magnetocaloric and magnetoresistance properties in Co based $\left(\mathrm{Co}_{0.402} \mathrm{Fe}_{0.201} \mathrm{Ni}_{0.067} \mathrm{~B}_{0.227}\right.$ $\left.\mathrm{Si}_{0.053} \mathrm{Nb}_{0.05}\right)_{100-\mathrm{x}} \mathrm{Cu}_{\mathrm{x}}(\mathrm{x}=0-1)$ glassy alloys. Philos. Mag. 2016, 96, 3120-3130. [CrossRef]

24. Gschneidner Jr, K.A.; Pecharsky, V.K. Magnetocaloric materials. Annu. Rev. Mater. Sci. 2000, 30, 387-429. [CrossRef]

25. Wang, G.; Zhao, Z.; Zhang, X.; Li, H.; Zhao, G. Peculiar effect of rare earth doping on magnetic and magnetocaloric properties in Fe-rich amorphous ribbons. J. Alloys Compd. 2018, 735, 104-108. [CrossRef] 